\title{
THE CHANGES IN CEREBRAL VASCULAR RESISTANCE OF MAN IN EXPERIMENTAL ALKALOSIS AND ACIDOSIS ${ }^{1}$
}

\author{
By JAMES F. SCHIEVE ${ }^{2}$ aNd WILLIAM P. WILSON
}

\author{
(From the Departments of Medicine and Psychiatry, Duke University School of Medicine, \\ Durham, N. C.)
}

(Submitted for publication July 3, 1952; accepted October 8, 1952)

Available evidence suggests that cerebral vascular resistance in man is primarily under chemical control. Past studies indicate that neurogenic stimuli, hormonal influences and most drugs have little ability to dilate cerebral vessels significantly. The potent chemical regulators which dilate cerebral vessels have been shown to be:1) anoxia and 2) either $\mathrm{CO}_{2}$ retention or decrease in the $\mathrm{pH}$ of arterial blood $(1,2)$. Using the nitrous oxide technique, Kety found increased cerebral blood flow $(\mathrm{CBF})$ in subjects breathing 10 per cent $\mathrm{O}_{2}$. $\mathrm{He}$ also showed that the increased CBF of respiratory acidosis produced by breathing 5 per cent or 7 per cent $\mathrm{CO}_{2}$ was associated with increased $\mathrm{CO}_{2}$ content and a lowered $\mathrm{pH}$ of arterial blood and decreased $\mathrm{CBF}$ of respiratory alkalosis following hyperventilation with a lowered $\mathrm{CO}_{2}$ content and elevated $\mathrm{pH}$.

Because of a tendency to an increase in CBF in late stages of diabetic acidosis, it was suggested originally by Kety, Polis, Nadler, and Schmidt (3) that the $\mathrm{pH}$ level might be more important than the $\mathrm{CO}_{2}$ content in regulation of cerebral vascular tone. This viewpoint has been stated by others $(4,5)$. Some doubt about this interpretation is suggested by earlier findings of Bronk and Gesell (6). In 1927, they found that intravenous injection of sodium carbonate and sodium bicarbonate increased blood flow in the femoral and the carotid arteries of dogs under anesthesia.

The present study attempts to separate the effect on cerebral vessels of changes in $\mathrm{pH}$ and $\mathrm{CO}_{2}$ content. By infusing $\mathrm{NaHCO}_{3}$ and $\mathrm{NH}_{4} \mathrm{Cl}$ intravenously, metabolic alkalosis and acidosis, re-

1 This investigation was supported by the Life Insurance Medical Research Fund (in part), by Air Force Contract 33(038)-27878 (in part), and by a research grant from the National Heart Institute, of the National Institutes of Health, Public Health Service (in part).

2 American Heart Association Research Fellow. Present adress: Department of Medicine, Ohio State University, Columbus, Ohio. spectively, were produced in man. The changes which occurred in $\mathrm{CBF}$ and cerebral vascular resistance were noted and compared to the changes previously reported after respiratory acidosis and alkalosis.

\section{METHOD}

The subjects studied were patients on the Medical Service of Duke Hospital. They were convalescing from a variety of illnesses and cannot be considered as a group of normal people. Six subjects were patients at Butner State Hospital. These patients were ill with schizophrenia and presented no physical illnesses. Metabolic alkalosis was produced by intravenous infusion of 1000 $\mathrm{ml}$. of 3 per cent $\mathrm{NaHCO}_{3}$ or $1000 \mathrm{ml}$. of 1.2 per cent $\mathrm{NaHCO}_{3}$ over a period of sixty minutes. Metabolic acidosis was established by slower infusion of approximately $350 \mathrm{cc}$. of 0.8 per cent $\mathrm{NH}_{4} \mathrm{Cl}$ intravenously over a period of 60 to 90 minutes. $\mathrm{NH}_{4} \mathrm{Cl}$ caused slight hyperpnea, and nausea occurred if the speed of the infusion was increased. Changes in pulse rate and blood pressure did not occur if the drip rate was kept below the nausea threshold.

The effect of changes in blood volume was determined by administering $1000 \mathrm{ml}$. of 0.85 per cent $\mathrm{NaCl}$ solution intravenously over a period of one hour. The effects of both volume change and hypertonicity on the cerebral circulation were observed after the intravenous administration of $1000 \mathrm{ml}$. of 2 per cent $\mathrm{NaCl}$ solution over a period of one hour.

Cerebral blood flow (CBF) was measured, using the nitrous oxide technique described by Kety and Schmidt (7) and modified by Scheinberg and Stead (8). Oxygen differences in volume per cent $\left(\mathrm{A}-\mathrm{VO}_{2}\right)$ were determined by the method of Hickam and Frayser (9) on the integrated arterial and cerebral venous blood specimens, respectively, or on the arterial and venous blood samples obtained immediately before and after the patient breathed $\mathrm{N}_{2} \mathrm{O}$. Cerebral metabolic rate of oxygen consumption $\left(\mathrm{CMRO}_{2}\right)$ in cubic centimeters of oxygen used per minute, per 100-grams of brain, was calculated by multiplying the rate of $\mathrm{CBF}$ in cc./min. $/ 100 \mathrm{gms}$. of brain by the $\mathrm{A}-\mathrm{VO}_{2}$ differences in volumes per cent. Arterial blood $\mathrm{pH}$ changes were determined anaerobically by a glass electrode, using a Beckman $\mathrm{pH}$ meter, and the readings were corrected to $37^{\circ} \mathrm{C}$. Arterial blood hemoglobin levels were measured, using spectrophotometric methods. Blood pressure readings were made by the auscultatory method, using a sphygmomanometer with the arm held at heart 
TABLE I

Effect of a 60-minute intravenous infusion of $1000 \mathrm{ml}$. of isotonic $\mathrm{NaCl}(0.9 \%)$ in six subjects

\begin{tabular}{lccccccc}
\hline \hline & Control & *S.D. & tS.E. & Experiment & S.D. & S.E. & p Value \\
\hline $\begin{array}{l}\mathrm{CBF} \\
\text { ml./min./100-grams brain }\end{array}$ & 60 & \pm 17 & \pm 7 & 60 & \pm 14 & \pm 6 & n.s. \\
$\begin{array}{l}\mathrm{A}-\mathrm{VO}_{2} \text { Difference } \\
\text { vols. \% }\end{array}$ & 6.5 & \pm 1.3 & \pm .5 & 6.2 & \pm .9 & \pm .4 & n.s. \\
$\begin{array}{l}\mathrm{CMRO}_{2} \\
\text { ml. } \mathrm{O}_{2} \text { used/min./100-grams brain }\end{array}$ & 3.7 & \pm .5 & \pm .2 & 3.7 & \pm .6 & \pm .2 & n.s. \\
$\begin{array}{l}\mathrm{CVR} \\
\text { (mean arterial BP/CBF) }\end{array}$ & 1.7 & \pm 1 & \pm .6 & 1.6 & \pm .8 & \pm .5 & n.s. \\
$\begin{array}{l}\text { Arterial pH } \\
\text { units }\end{array}$ & 7.36 & \pm .01 & \pm .005 & 7.35 & \pm .01 & \pm .005 & n.s. \\
$\begin{array}{l}\text { Arterial Hemoglobin } \\
\text { grams \% }\end{array}$ & 14.0 & \pm 1.1 & \pm .5 & 12.7 & \pm 1 & \pm .5 & .05 \\
\hline
\end{tabular}

$$
\text { * Standard Deviation }=S=\frac{\sqrt{\Sigma x^{2}-\frac{(\Sigma x)^{2}}{N}}}{N-1}
$$

level. The mean arterial blood pressure was calculated by adding one-third of the pulse pressure to the diastolic blood pressure.

In each study, the CBF was measured by the $\mathrm{N}_{2} \mathrm{O}$ technique, both before and during infusions of $\mathrm{NaHCO}_{8}, \mathrm{NaCl}$, and $\mathrm{NH}_{4} \mathrm{Cl}$. In five instances after infusion of $\mathrm{NaHCO}_{3}$, and in one instance after infusion of $\mathrm{NH}_{4} \mathrm{Cl}$, the patient breathed 5 per cent $\mathrm{CO}_{2}$ for four minutes. In these six instances, the changing $\mathrm{A}-\mathrm{VO}_{2}$ difference before and during $\mathrm{CO}_{2}$ inhalation was measured. From the change in $\mathrm{A}-\mathrm{VO}_{2}$ difference, a third cerebral blood flow was estimated utilizing the fact that during 5 per cent $\mathrm{CO}_{2}$ inhalation, $\mathrm{CMRO}_{2}$ remains constant (2).

\section{RESULTS}

\section{Control studies with saline}

The results recorded in Table I show that intravenous infusion of $1000 \mathrm{ml}$. of isotonic ( 0.9 per cent) saline over sixty minutes has no effect on $\mathrm{CBF}$, or $\mathrm{CMRO}_{2}, \mathrm{~A}-\mathrm{VO}_{3}$ difference, or $\mathrm{pH}$ of arterial blood. Significant decreases in hemoglobin values occur, indicating a measurable degree of hemodilution. Table II shows the results in six patients after infusion of $1000 \mathrm{ml}$. of 2 per cent $\mathrm{NaCl}$. This is approximately isotonic with a 3 per cent solution of $\mathrm{NaHCO}_{3}$. There is a 10 per cent, but statistically insignificant, increase in $\mathrm{CBF}$. A significant narrowing in $\mathrm{A}-\mathrm{VO}_{2}$ difference does occur. This, combined with the directional change in cerebral blood flow, suggests that hypertonic saline solution does increase cerebral blood flow. We have no ready explanation for this effect. Hemodilution of approximately the same magnitude occurred with both isotonic and hypertonic saline, and neither changed $\mathrm{pH}$ significantly.

\section{Metabolic alkalosis}

Tables III and IV show the effect of intravenous infusions of approximately $1000 \mathrm{ml}$. of isotonic (1.2 per cent) and hypertonic ( 3 per cent $\mathrm{NaHCO}_{3}$ ), respectively. Similar results occur in both instances, but the changes are greater after 3 per cent $\mathrm{NaHCO}_{3}$, suggesting a quantitative action of the bicarbonate ion. The increase in blood flow with hypertonic $\mathrm{NaHCO}_{3}$ solution is greater than that produced by hypertonic $\mathrm{NaCl}$ solution. The sharp increase in CBF after 3 per cent $\mathrm{NaHCO}_{3}$ is comparable to that found after inhalation of 5 per cent $\mathrm{CO}_{2}$. The increased CBF after bicarbonate infusion is associated with an increased $\mathrm{pH}$ of arterial blood. The increased CBF after $\mathrm{CO}_{2}$ inhalation is associated with decreased $\mathrm{pH}$ of arterial blood.

Although $\mathrm{CO}_{2}$ tensions were not measured in the $\mathrm{NaHCO}_{3}$ infusion experiments reported here, other studies (10-12) suggest that after $\mathrm{NaHCO}_{3}$ infusion, the $\mathrm{CO}_{2}$ tension changes are minimal, while changes in the bicarbonate ion content are great. The absence of visible changes in respiratory rate and depth after $\mathrm{NaHCO}_{3}$ infusion also suggests little change in $\mathrm{CO}_{2}$ tension. 
TABLE II

Effect of a 60-minute intravenous infusion of $1000 \mathrm{ml}$. of hypertonic $\mathrm{NaCl}(2.0 \%)$ in seven subjects

\begin{tabular}{|c|c|c|c|c|c|c|c|}
\hline & Control & S.D. & S.E. & Experiment & s.D. & S.E. & D Value \\
\hline $\begin{array}{l}\text { CBF } \\
\mathrm{ml} . / \mathrm{min} . / 100 \text {-grams brain }\end{array}$ & 59 & \pm 12 & \pm 5 & 66 & \pm 16 & \pm 6 & n.s. \\
\hline $\begin{array}{l}\mathrm{A}-\mathrm{VO}_{2} \text { Difference } \\
\text { vols. } \%\end{array}$ & 6.2 & \pm .95 & \pm .4 & 5.0 & \pm .5 & \pm .2 & .01 \\
\hline $\begin{array}{l}\mathrm{CMRO}_{2} \\
\mathrm{ml} . \mathrm{O}_{2} \text { used/min./100-grams brain }\end{array}$ & 3.6 & \pm .5 & \pm .2 & 3.3 & \pm .8 & \pm .3 & n.s. \\
\hline $\begin{array}{l}\text { CVR } \\
\text { (mean arterial } \mathrm{BP} / \mathrm{CBF} \text { ) }\end{array}$ & 1.5 & \pm .4 & \pm .1 & 1.4 & \pm .4 & \pm .2 & n.s. \\
\hline $\begin{array}{l}\text { Arterial pH } \\
\text { units }\end{array}$ & 7.35 & \pm .01 & \pm .007 & 7.33 & \pm .02 & \pm .01 & n.s. \\
\hline $\begin{array}{l}\text { Arterial Hemoglobin } \\
\text { grams } \%\end{array}$ & 13.0 & \pm 1.4 & \pm .6 & 11.5 & \pm 1 & \pm .4 & .05 \\
\hline
\end{tabular}

TABLE III

Effects of a 60-minute intravenous infusion of $1000 \mathrm{ml}$. of isotonic $\mathrm{NaHCO}_{2}(1.2 \%)$ in six subjects

\begin{tabular}{|c|c|c|c|c|c|c|c|}
\hline & Control & S.D. & S.E. & Experiment & S.D. & S.E. & p Value \\
\hline $\begin{array}{l}\mathrm{CBF} \\
\mathrm{ml} . / \mathrm{min} . / 100 \text {-grams brain }\end{array}$ & 60 & \pm 12 & \pm 5 & 78 & \pm 18 & \pm 7 & .1 to .05 \\
\hline $\begin{array}{l}\mathrm{A}-\mathrm{VO}_{2} \text { Difference } \\
\text { vols. } \%\end{array}$ & 6.1 & \pm .8 & \pm .3 & 5.1 & \pm .7 & \pm .3 & .02 \\
\hline $\begin{array}{l}\mathrm{CMRO}_{2} \\
\mathrm{ml} . \mathrm{O}_{2} \text { used } / \mathrm{min} . / 100 \text {-grams brain }\end{array}$ & 3.6 & \pm .6 & \pm .2 & 3.9 & \pm .5 & \pm .2 & n.s. \\
\hline $\begin{array}{l}\text { CVR } \\
\text { (mean arterial BP/CBF) }\end{array}$ & 1.6 & \pm .3 & \pm .05 & 1.2 & \pm .2 & \pm .04 & .05 \\
\hline $\begin{array}{l}\text { Arterial pH } \\
\text { units }\end{array}$ & 7.39 & \pm .01 & \pm .004 & 7.48 & \pm .01 & \pm .005 & .01 \\
\hline $\begin{array}{l}\text { Arterial Hemoglobin } \\
\text { grams \% }\end{array}$ & 12.3 & \pm .8 & \pm .3 & 11.3 & \pm 1.7 & \pm .7 & n.s. \\
\hline
\end{tabular}

TABLE IV

Effect of a 60-minute intravenous infusion of $1000 \mathrm{ml}$. of hypertonic $\mathrm{NaHCO}$ (3\%) in ten subjects

\begin{tabular}{|c|c|c|c|c|c|c|c|}
\hline & Control & S.D. & S.E. & Experiment & S.D. & S.E. & p Value \\
\hline $\begin{array}{l}\text { CBF } \\
\text { ml./min./100-grams brain }\end{array}$ & 52 & \pm 11 & \pm 3 & 88 & \pm 15 & \pm 5 & .01 \\
\hline $\begin{array}{l}\mathrm{A}-\mathrm{VO}_{2} \text { Difference } \\
\text { vols. } \%\end{array}$ & 6.9 & \pm 1.4 & \pm .4 & 4.2 & \pm .7 & \pm .2 & .01 \\
\hline $\begin{array}{l}\mathrm{CMRO}_{2} \\
\mathrm{ml} . \mathrm{O}_{2} \text { used/min./100-grams brain }\end{array}$ & 3.6 & \pm 1.1 & \pm .3 & 3.4 & \pm .8 & \pm .3 & n.s. \\
\hline $\begin{array}{l}\text { CVR } \\
\text { (mean arterial } \mathrm{BP} / \mathrm{CBF} \text { ) }\end{array}$ & 1.8 & \pm .4 & \pm .1 & 1.1 & \pm .3 & \pm .1 & .01 \\
\hline $\begin{array}{l}\text { Arterial pH } \\
\text { units }\end{array}$ & 7.34 & \pm .03 & \pm .01 & 7.52 & \pm .02 & \pm .006 & .01 \\
\hline $\begin{array}{l}\text { Arterial Hemoglobin } \\
\text { grams \% }\end{array}$ & 13.6 & \pm 1.3 & \pm .4 & 12.2 & \pm 1.4 & \pm .4 & .02 \\
\hline
\end{tabular}


TABLE V

Effect of a 60 to 90-minute intravenous infusion of 350 cc. of $\mathrm{NH}_{4} \mathrm{Cl}(0.8 \%)$ in seven subjects

\begin{tabular}{|c|c|c|c|c|c|c|c|}
\hline & Control & S.D. & S.E. & Experiment & S.D. & S.E. & p Value \\
\hline $\begin{array}{l}\text { CBF } \\
\mathrm{ml} . / \mathrm{min} . / 100 \text {-grams brain }\end{array}$ & 66 & \pm 12 & \pm 5 & 52 & \pm 8 & \pm 3 & .05 to .02 \\
\hline $\begin{array}{l}\mathrm{A}-\mathrm{VO}_{2} \text { Difference } \\
\text { vols. } \%\end{array}$ & 6.3 & \pm .5 & \pm .2 & 8.6 & \pm .8 & \pm .3 & .01 \\
\hline $\begin{array}{l}\mathrm{CMRO}_{2} \\
\mathrm{ml} . \mathrm{O}_{2} \text { used/min./100-grams brain }\end{array}$ & 4.2 & \pm .7 & \pm .3 & 4.4 & \pm .5 & \pm .2 & n.s. \\
\hline $\begin{array}{l}\text { CVR } \\
\text { (mean arterial } \mathrm{BP} / \mathrm{CBF})\end{array}$ & 1.3 & \pm .3 & \pm .1 & 1.6 & \pm .5 & \pm .1 & .01 \\
\hline $\begin{array}{l}\text { Arterial } \\
\frac{\mathrm{pH}}{\text { units }}\end{array}$ & 7.36 & \pm .014 & \pm .005 & 7.32 & \pm .016 & \pm .006 & .05 \\
\hline$\frac{\mathrm{CO}_{2} \text { content }}{\text { vols. } \%}$ & 50 & \pm 3 & \pm 1 & 46 & \pm 3 & \pm 1 & .1 to .05 \\
\hline$\frac{\text { Hemoglobin }}{\text { grams \% }}$ & 13.0 & \pm 2 & \pm .7 & 12.4 & \pm 2 & \pm .6 & n.s. \\
\hline$\frac{\mathrm{p} \mathrm{CO}}{\mathrm{mm} \cdot \mathrm{Hg}}$ & 48 & \pm 7 & \pm 3 & 47 & \pm 5 & \pm 2 & n.s. \\
\hline
\end{tabular}

\section{Metabolic acidosis}

In Table $\mathrm{V}$ are recorded the effects of the slow infusion of 0.8 per cent $\mathrm{NH}_{4} \mathrm{Cl}$ on the cerebral circulation. There is a reduction in blood flow, the $\mathrm{A}-\mathrm{VO}_{2}$ difference widens greatly, and no change in $\mathrm{CMRO}_{2}$ occurs. There is a consistent drop in arterial $\mathrm{pH}$ and serum $\mathrm{CO}_{2}$ content and very little change in $\mathrm{CO}_{2}$ tension. Thus, metabolic acidosis, as produced by $\mathrm{NH}_{4} \mathrm{Cl}$ is accompanied by a reduction of $\mathrm{CBF}$, in contrast to respiratory acidosis in which CBF is increased. Metabolic acido-

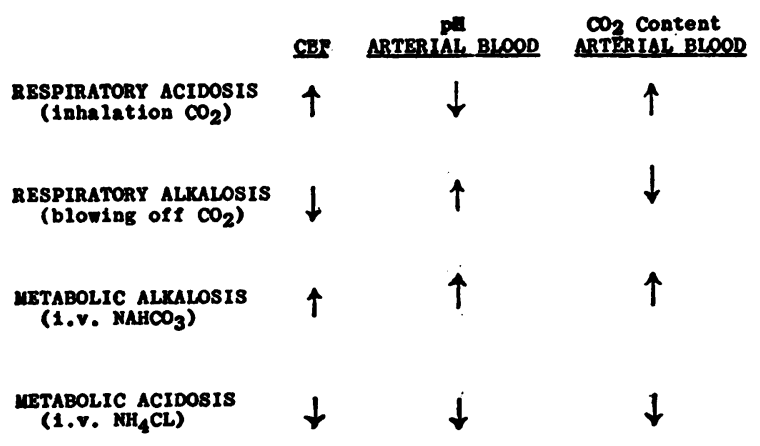

Fig. 1. This Chart Shows the Directional Changes in CBF Arterial pH and Arterial CO, Content as Found by Kety and Schmidt in Respiratory Acidosis and Alkalosis and by This Study in Metabolic Alkalosis and Acidosis sis produced in some other fashion than by $\mathrm{HN}_{4} \mathrm{Cl}$ should be studied. It is possible that we are really measuring, in part, the effects of $\mathrm{NH}_{4}$ ion rather than the uncomplicated effects of acidosis.

\section{Carbon dioxide inhalation in metabolic alkalosis and acidosis}

In Figures 1 and 2 are schematically drawn the effect of $\mathrm{CO}_{2}$ when breathed by alkalotic and acidotic subjects, respectively. When the subject who is alkalotic from $\mathrm{NaHCO}_{3}$ breathes $\mathrm{CO}_{2}$, a sharp further increase in $\mathrm{CBF}$ occurs while $\mathrm{pH}$ returns toward, but does not quite reach, prebicarbonate levels. Similarly demonstrated, but in a reverse fashion, are the results (Figure 2) in a metabolic acidotic subject who breathes $\mathrm{CO}_{2}$. Here, CBF increases above pre-ammonium chloride levels while $\mathrm{pH}$ becomes even lower.

\section{DISCUSSION}

Sodium bicarbonate increases cerebral flow by decreasing cerebral vascular resistance. $\mathrm{NH}_{4} \mathrm{Cl}$ decreases cerebral blood flow by increasing cerebral vascular resistance. Earlier studies (2) have shown that increased and decreased amounts of carbon dioxide in the arterial blood increase and decrease $\mathrm{CBF}$, respectively. The summary chart 


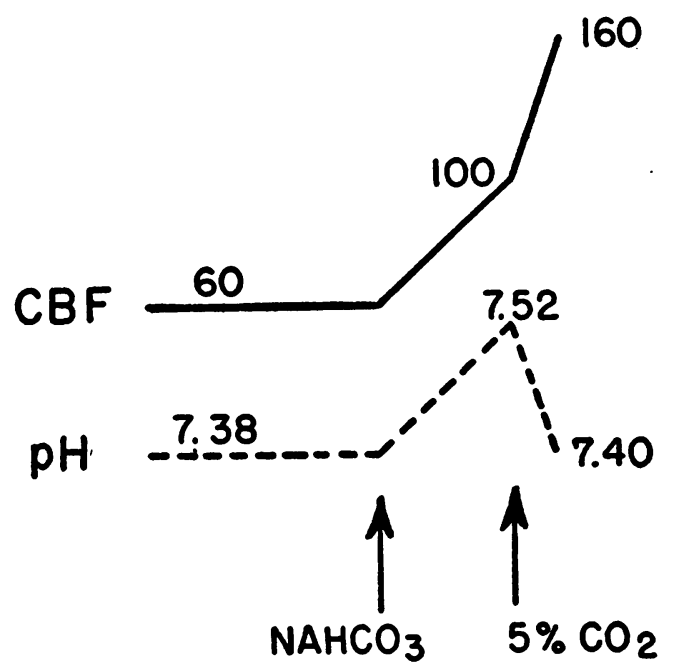

Fig. 2. Schematically Drawn are the Changes in CBF and pH of Arterial Blood Before and During the Administration of $1000 \mathrm{ML}$. of 3 Per Cent NaHCO. Over a 60-Minute Time Period

At the second arrow, 5 per cent $\mathrm{CO}_{2}$ was inhaled and the changes recorded occurred after four minutes.

(Figure 3) indicates by arrow the directional changes in $\mathrm{CBF}, \mathrm{pH}$ and $\mathrm{CO}_{2}$ content which occur in respiratory acidosis and alkalosis as described by Kety, and metabolic alkalosis and acidosis as found in this study. When one compares the directional changes in arterial blood $\mathrm{pH}$ with
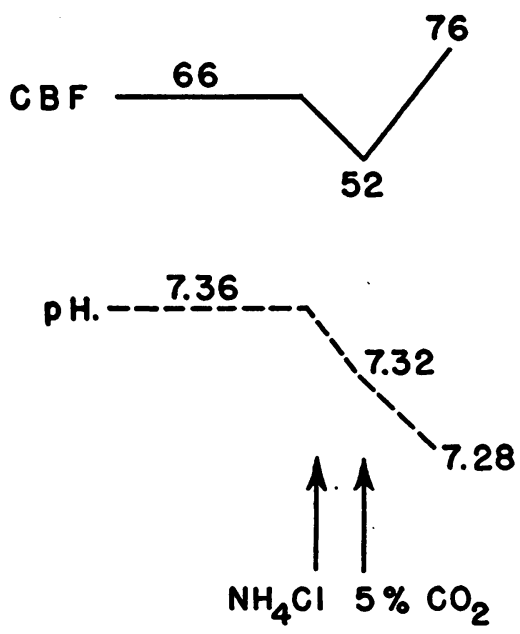

Fig. 3. Schematically Drawn are the Changes in CBF and pH of Arterial Blood Before and After Intravenous Infusion of 0.8 Per Cent NH.Cl Over a Period of 60 to 90 Minutes

At the second arrow 5 per cent $\mathrm{CO}_{2}$ was inhaled and the changes recorded occurred after four minutes. cerebral blood flow changes, no correlation exists. However, when one compares the directional changes in total $\mathrm{CO}_{2}$ content of arterial blood with those of $\mathrm{CBF}$, one finds complete correlation.

\section{CONCLUSIONS}

1. Metabolic alkalosis, as produced by giving 3 per cent $\mathrm{NaHCO}_{3}$ solution intravenously, increases $\mathrm{CBF} 65$ per cent above resting normal values; isotonic bicarbonate solution (1.2 per cent) causes a 30 per cent increase.

2. The increase in $\mathrm{CBF}$ after $\mathrm{NaHCO}_{3}$ is not primarily due to changes in intravascular volume because an equivalent degree of hemodilution produced by the infusion of isotonic $\mathrm{NaCl}$ solution does not cause an increase in CBF.

3. Infusion of 2 per cent $\mathrm{NaCl}$ solution does cause a demonstrable increase in CBF. It is not of the order of magnitude produced by the infusion of an equally hypertonic solution of $\mathrm{NaHCO}_{3}$.

4. Intravenous infusion of 0.8 per cent $\mathrm{NH}_{4} \mathrm{Cl}$ solution reduced $\mathrm{CBF}$ approximately 20 to 25 per cent.

5. These studies, when coupled with previous studies of Kety, show that-in the absence of anoxia-cerebral vascular tone is more closely related to total $\mathrm{CO}_{2}$ content of arterial blood rather than arterial $\mathrm{pH}$ levels.

\section{ACKNOWLEDGMENTS}

The authors are indebted to Dr. James P. Murdock, Superintendent, State Hospital, Butner, North Carolina, for his invaluable cooperation. These studies were done with the technical assistance of Miss Melba Holder, Mrs. Mary Robertson and Mrs. Helen Rowe.

\section{REFERENCES}

1. Kety, S. S., Circulation and metabolism of the human brain in health and disease. Am. J. Med., 1950, 8, 205.

2. Kety, S. S., and Schmidt, C. F., The effects of altered arterial tensions of carbon dioxide and oxygen on cerebral blood flow and cerebral oxygen consumption of normal young men. J. Clin. Invest., 1948, 27, 484.

3. Kety, S. S., Polis, B. D., Nadler, C. S., and Schmidt, C. F., The blood flow and oxygen consumption of the human brain in diabetic acidosis and coma. J. Clin. Invest., 1948, 27, 500.

4. Patterson, J. L., Jr., Heyman, A., and Duke, T. W., 
Cerebral circulation and metabolism in chronic pulmonary emphysema. Am. J. Med., 1952, 12, 382.

5. Scheinberg, P., and Jayne, H. W., Factors influencing cerebral blood flow and metabolism. A review. Circulation, 1952, 5, 225.

6. Bronk, D. W., and Gesell, R., The regulation of respiration. $\mathrm{X}$. Effects of carbon dioxide, sodium bicarbonate and sodium carbonate on the carotid and femoral flow of blood. Am. J. Physiol., 1927, 82, 170.

7. Kety, S. S., and Schmidt, C. F., The determination of cerebral blood flow in man by the use of nitrous oxide in low concentrations. Am. J. Physiol., 1945, 143, 53.

8. Scheinberg, P., and Stead, E. A., Jr., The cerebral blood flow in male subjects as measured by the nitrous oxide technique. Normal values for blood flow, oxygen utilization, glucose utilization, and peripheral resistance, with observations of the effect of tilting and anxiety. J. Clin. Invest., 1949, 28, 1163.

9. Hickam, J. B., and Frayser, R., Spectrophotometric determination of blood oxygen. J. Biol. Chem., 1949, 180, 457.

10. Davies, H. W., Haldane, J. B. S., and Kennaway, E. L., Experiments on the regulation of the blood's alkalinity. J. Physiol., 1920, 54, 32.

11. Hooker, D. R., Wilson, D. W., and Connett, H., The perfusion of the mammalian medulla: The effect of carbon dioxide and other substances on the respiratory and cardio-vascular centers. Am. J. Physiol., 1917, 43, 351.

12. Scott, R. W., The significance of undissociated carbon dioxide in respiration. Am. J. Physiol., 1918, 47, 43. 